\title{
Enhancing Students' Class Participation through Gamification: Creating Motivational Affordance, Psychological and Behavioral Outcomes
}

\author{
Hafizah Abd-Mutalib*, Ifa Rizad Mustapa, Danilah Salleh \\ Tunku Puteri Intan Safinaz School of Accountancy, Universiti Utara Malaysia, Malaysia
}

Received July 9, 2019; Revised September 9, 2019; Accepted September 16, 2019

Copyright $\odot 2019$ by authors, all rights reserved. Authors agree that this article remains permanently open access under the terms of the Creative Commons Attribution License 4.0 International License

\begin{abstract}
Purpose: The purpose of this study is to examine if the method of gamification may improve students' class participation during the deliverance of course content. Drive by Self-Determination Theory (SDT), this study believes that motivational affordance resulted from gamification activity may lead to psychological outcome, and this psychological outcome will lead to behavioural outcome. Methodology: The study was conducted using qualitative action research methodology with descriptive analysis in two classes of Enterprise Strategy course. Three phases were involved for data gathering. Main Findings: In phase 1, when traditional lecture was solely used, students seemed to be passive, indifferent and reluctant to participate. In phase 2, when traditional lecture is supplanted with gamification activity, students have participated actively. Similar results of phase 2 was found in phase 3 , where different set of students were observed. Students also perceived that using gamification in classroom provide enjoyable and fun environment, attractive and exciting, besides enhancing knowledge. Students also perceived that gamification activity increases participation, improving motivation, creating competition, developing teamwork and bonding between students and instructor and should be conducted more. Application: The results of this study may be beneficial to students in term of new technique used in teaching and learning process through enhancement of knowledge circulation from lecturers to students or between the students themselves. The results may also heighten the awareness of instructors in identifying alternative tools besides conducting traditional lectures. The results also may encourage administrators in helping the instructors towards upgrading their teaching methods and performance using latest applications for the purpose of improving students' engagement. Novelty/Originality: The findings from study add to the body of knowledge on the significance of using gamification in classroom in order to engage students in classroom activity.
\end{abstract}

Keywords Gamification Approach, Motivational Affordance, Psychological Outcome, Behavioural Outcome, Self-Determination Theory

\section{Introduction}

For decades, traditional lecture has become an important or main medium in higher learning classroom delivery. Traditional lecture involves the method of transmitting the course content by a teacher, and students will listen and take notes on the information transmitted. In other words, traditional lecture may also be referred to the transmission of the lecturer's knowledge from their notes to the students' notepads (Isaacs, 1989).

Traditional lecture has its own advantages. For instance, it enables the teacher, lecturer or instructor to cover the necessary content in an allocated time; where instructors can make knowledge more meaningful by relating the lecture content to the students' prior knowledge and relate it to real life examples (Dolnicar, 2005). Despite these advantages, traditional lecture also has its own drawbacks. Isaac (1989) suggests that the transmission of the lecturer's knowledge from their notes to the students' notepads is mostly lack of thinking or processing of information. Furthermore, traditional lecture encourages intellectual passivity, as students will exhibit low level of engagement (McGarr, 2009).

The drawbacks of traditional lecture have triggered the development of alternative teaching and learning methods which may encourage students' participation in classroom. The advancement and innovation of technology has provided alternatives to overcome the students' passiveness in class, thus making the classroom active and enjoyable. Among the techniques is gamification, which refers to the usage of the elements of games in non-game 
contexts (Deterding, 2011) with the goal of engaging people in a variety of tasks (Borges, Durelli, Reis et al., 2014). With the help of the advancing technology, the traditional lectures should no longer be the main teaching and learning technique, but it should be as much as possible being complimented by other active learning methods (Aliaga, Cobb, Cuff et al., 2010). Therefore, the purpose of this study is to examine if the method of gamification may improve students' class participation during the deliverance of course content.

This study applies Self-determination Theory (SDT) in explaining the motivation and outcomes that may result from gamification in classroom. SDT concerns about the choices humans made, and the motivation that drives humans to arrive at the choices. Motivations can be classified into the extrinsic and intrinsic motivation (Ryan and Decci, 2000), and is said to be afforded when the relation between the features of an object and the abilities of a subject allow the subject to experience the satisfaction of such needs when interacting with the object (Deterding, 2011). This motivation, according to Deterding (2011) is being referred to as motivational affordance. In gamification context, if the players believe that they can follow the rules and feel that they are able to attain the reward, the players are said to have the motivational affordance.

Motivational affordance that is created in the gamification process leads to users' experiential value creation (Sigala, 2015) in the forms of psychological or behavioral outcome (Hamari, Koivisto, \& Sarsa, 2014; Sigala, 2015). Behavioral outcome may be viewed in the form of players' participation, task completion time and number of players participating (Sigala, 2015), while psychological outcome usually be interpreted as enjoyment and motivation (Sigala, 2015).

The focus of this study is to observe if gamification has effect on students' participation, and whether students' participation, which results from the gamification activities, may create chain of effects for generating motivational affordances thus creating psychological outcomes to the players or users (Hamari et al., 2014). The psychological outcomes will in turn lead to behavioral outcomes (Hamari et al., 2014).

From the researchers' own observations and experiences in previous classrooms, when using traditional lectures, students usually perceive that the instructor is responsible to conduct the class, and to provide them with the materials and inputs of the courses. However, students fail to realize their own responsibility in understanding the course content. These situations create passive atmosphere in the classroom, where students rarely respond to the contents from the traditional lectures. Since students perceive that the instructors play significant role in the teaching process, students' level of participation towards the lesson will be as minimal as possible. Therefore, it is crucial for the researchers, as the instructors in class, to apply different technique to enhance students' participation in classroom.
Many applications can be applied as mediums to conduct games in classrooms by the 21st century instructors, and these applications may be used by the instructors to support gamification in classroom. The interest towards gamification in education generally, and in classroom specifically, whether in its application or implications is growing, as gamification provides an alternative to engage and motivate students during the process of learning (Borges et al., 2014). Previous studies suggest that students do not participate in class because they do not feel entitled to do so. They feel like they lack power, as such, they are more likely to be silent (Vandrick, 2000). Therefore, by using applications that support gamifications in classroom, instructors may provide a non-threatening space for the collection and curation of collaborative classroom work. As a result, students may have the chance and capability to contribute to each other and learn from one another (Fuchs, 2014). Gamifications may also reduce the barriers to students contributing to class discussions (Elis, 2015) and will encourage students to engage themselves in active learning activities (Dellos, 2015). As such, the researchers expect that with the gamification technique, the low level of participation in the researchers' classrooms may be resolved.

This study provides a number of significance. For students, it will benefit in term of new technique used in the teaching and learning process through enhancement of the circulation of knowledge from lecturers to students or between the students themselves through participation in class discussions. For lecturer, this study may heighten their awareness in identifying the alternative tools besides conducting traditional lectures. Lecturers or instructors may become aware that there are some tools or applications that may be utilized in classroom in order to avoid mundane atmosphere in teaching and learning session. This study also may benefit the faculty administrators, where the results of this investigation may encourage administrators and supervisors help their lecturers upgrade their teaching performance and utilize the latest applications in improving students' participation through gamification apps.

The rest of this paper is organized as follows: literature review and methodology, followed by findings, discussions, conclusion and the avenue for future research.

\section{Literature Review}

This section presents the literature review of studies conducted on gamification in education and the theory used in this study, which is the Self Determination Theory (SDT).

\subsection{Gamification}

Surendeleg, Murwa, Yun et al. (2014) explained gamification as a concept that aims to increase the 
experience of users and their engagement to a system, and the field of education is not left behind in term of the application of gamification in the teaching and learning process. Using the game elements in non-game contexts, gamification focuses on engaging people to do variety of tasks (Borges et al., 2014; Deterding, 2011). Gamification is also found to be used as an effective tool towards engaging and motivating users in non-entertainment context (Seaborn \& Fels, 2015). It is also being referred to as using game-based mechanics, aesthetics and game thinking to engage people, motivation action, promote learning and solve problems (Kapp, 2012). As a tool with the goal of engaging people in a variety of tasks (Borges et al., 2014), gamification involves the element of "gamefulness, gameful interaction and gameful design" (Deterding, 2011).

In education context, gamification refers to the educational approach to motivate students to learn by using game design elements in learning environment (Hamari et al., 2014; Kapp, 2012; Takahashi, 2008) and how to make learning interesting (Lee \& Hammer, 2011; O'Donovan, Gain, \& Marais, 2013). It relies on the motivational power characteristics of good games, which can deliver information and demand within context (Gee, 2003), balancing challenge based on abilities, thus, prevents players from becoming bored or frusterated (Barata, Gama, Jorge et al., 2013), thus is an effective approach to make positive change in students' behavior and attitude towards learning (Kiryakova, Angelova, \& Yordanova, 2014). It is important to understand the role of gamification, as by doing so, instructors may understand the conditions on how the gamification may lead to a desired learning behavior (Lee \& Hammer, 2011).

\subsection{Previous Literature on Gamification in Classroom}

As all aspects of society, marketing, entertainment, commerce and health are changes due to current trend, education is not an exception, thus marks gamification as one of evolving style in education. A previous study explains that educators continue looking for a variety of many new tools to improve the quality of teaching and learning, and gamification method is among the new innovation in teaching and learning process (Surendeleg et al., 2014). Furthermore, a previous study also justify that using gamification such as computer games and serious games of earlier technology gives positive impact in teaching and learning process (Connoli, Boyle, MacArthur et al., 2012).

Gamification is a consequential technology of game and game-based approaches in field of education which have sturdily been investigated since eighties (Borges et al., 2014). Borges et al. (2014) stresses that gamification applications and implications have become an interest among researchers since it provides substitution to enchanting and motivating students during the process of learning (Borges et al., 2014). Hamari et al. (2014), studied the effects of gamification by conceptualizing and classifying related studies in broad area under the question of “Does Gamification work?” which focuses on its effects from a psychological perspective, while Thiebes et al. (2014) identify game elements used in gamification with a main concentration on user motivation (Thibes, Lins, \& Basten, 2014).

Game components are used as intrinsic and extrinsic factors to expand learner's motivation. Each component has its own role that touches student's behavior. For example, offering rewards is a kind of extrinsic motivation (de-Marcos, Dominguez, Saenz-de-Navarette et al., 2014). Badges: requirement should have difficulty (O'Donovan et al., 2013). Points and levels: should consist of challenges (O'Donovan et al., 2013). These components can get students in a community with other students and their achievements shown in public. In the reviewed experimental papers, the game components are assimilated into a various applications with the main goals of increasing student's engagement and satisfaction. The usage of game components or game mechanics design relys on the system's main contexts and purposes. In common, the most used components in gamified applications are feedbacks, leaderboards, points, and levels. Gamification is pictured as having low cost of development, while its components were found to be more 'delicious' or 'interesting' while surfing the learning content. Contradict to traditional instructional methodology which are perceived by students to be boring, gamification technology has great benefit to solve the traditional practice.

Barata et al. (2013) conducted a longitudinal study on students' participation when gamification is applied in the learning process. In the first three years of this study, non-gamified elements have been used, while in the last two years, students were being exposed to gamification. The results show significant improvements in term of attention to materials, online participation, proactivity and reducing grade discrepancies among students. Gamification setting in classroom has also seen in enhancing students' performance as they found games to be valuable in their learning (Nehring, Baghaei, \& Dacey, 2018).

\subsection{Self-Determination Theory (SDT)}

This study applies Self-determination Theory (SDT) in explaining the motivation and outcomes that may result from gamification in classroom. SDT concerns about the choices humans made, and the motivation that drives humans to arrive at the choices. Motivations can be classified into the extrinsic and intrinsic motivation (Ryan and Decci, 2000). Motivation is said to be afforded when the relation between the features of an object and the abilities of a subject allow the subject to experience the 
satisfaction of such needs when interacting with the object (Deterding, 2011). In other words, when a person believes that he has the abilities and skills to perform a given task, the person will have the kind of motivation to perform. This motivation, according to Deterding (2011) is being referred to as motivational affordance. For example, in a gamification setting, the players will usually be guided with rules that need to be followed and the rewards that can be obtained when a level/ levels have been achieved. Therefore, if the players believe that they can follow the rules and feel that they are able to attain the reward, the players are said to have the motivational affordance.

Motivational affordance that is created in the gamification process leads to users' experiential value creation (Sigala, 2015). The values created can be in the form of psychological or behavioral outcome (Hamari et al., 2014; Sigala, 2015). Psychological outcome usually be interpreted as enjoyment and motivation (Sigala, 2015), while behavioral outcome may be viewed in the form of players' participation, task completion time and number of players participating (Sigala, 2015). As a conclusion, this study focus on the effect of gamification, where the concept and aims are effectively implemented when the following chain of effects are achieved: game mechanics are used for triggering motivational affordances and creating psychological outcomes to the players or users in the form of enjoyment, which in turn lead to behavioral outcomes, in the form of participation (Hamari et al., 2014).

\section{Methodology}

This study employed qualitative action research with descriptive analysis. According to Mc Niff (2010), “Action research is a term which refers to a practical way of looking at your own work to check that it is as you would like it to be". Action research is done by the practitioner, and it involves oneself thinking about and reflecting on his/her work. Action research report shows how practitioner has carried out a systematic investigation into his/her own behaviour, and the reasons for that behaviour (McNiff, 2010).

This study was conducted in three phases, and the description of each phase is outlined below. In Phase 1 and Phase 2, students taking BKAM3073 (Enterprise Strategy) in A171 academic session were involved, while Phase 3 involved students taking the same course but in different academic session, which was A172 session. BKAM3073 was chosen for this study since this course is a fully theoretical course. As it is fully theoretical, students need to read a lot of materials and do a lot of discussion in class; therefore, participation is crucial for students to engage themselves in the discussions. Without students' participation, discussion would be passive and without energy, thus would become unrewarding. If students find that the materials are not so engaging, they will not spend enough time to gain deeper understanding on the subject matter (Nehring et al., 2018). Since this study concerns in enhancing students' participation, a fully theoretical course may give good indication on whether gamification approach may develop active atmosphere in course content deliverance. BKAM3073 is an elective course taken by students in final year of Bachelor in Accounting (Hons) and Bachelor in Accounting Information System (Hons) programmes in Tunku Puteri Intan Safinaz School of Accountancy, Universiti Utara Malaysia.

\subsection{Phase 1 - Traditional Lecture}

Phase 1 was divided between "pre-implementation" and "during implementation" phases. In the "pre-implementation" phase, students were provided with study materials in the form of lecture notes that was uploaded on the online-learning zone. The lecture notes concern on Topic 6 (Implementing Strategy and Controlling Plans). Students were instructed to read the first part of the materials (Performance Measurement Mix, Critical Success Factors and Key Performance Indicators), and to be ready for the next lecture.

In "during implementation” phase, instructor conducted traditional lecture on the first part of topic 6. After traditional lecture, students were asked to divide themselves into groups of 3-4 persons, and to make discussions on the topic lectured previously. Instructor asked questions, observed and recorded students' participation using Participation Rubric.

\subsection{Phase 2 - Gamification}

Phase 2 was also divided between "pre-implementation" and "during implementation" phases. Similar to Phase 1, students were provided with study materials in the form of lecture notes that was uploaded on the online-learning zone in the "pre-implementation" phase. With the second part of Topic 6 (Alternative Models of Measuring Strategic Performance), students were instructed to read the materials, and to be ready for the next lecture. In the "pre implementation" phase of Phase 2, students were informed that there would be a game conducted at the end of the class session, and the winning teams will receive rewards. This action marked the difference between Phase 1 and Phase 2.

In "during implementation" phase, traditional lecture took place. After the traditional lecture, instructor asked the students to group themselves into groups of 3-4 members per group. Each group were asked to discuss the contents lectured earlier. Instructor then once again announced that a game would take place after the discussion. After 10 minutes of discussion, instructor conducted a gamification activity using the Kahoot! application. Instructor observed and recorded students' participation using Participation Rubric. 
Gamification process created motivational affordance which in turn leads to experiential value creation (Sigala, 2015) in the forms of behavioral or psychological outcome (Hamari et al., 2014; Sigala, 2015). Previous studies postulated that behavioral outcome may be viewed in the form of players' participation, task completion time and number of players participating (Sigala, 2015), while psychological outcome usually be interpreted as enjoyment and motivation (Sigala, 2015). Therefore, this study used participation rubric which contains the element of contribution, attitude towards peers and instructor, preparedness, focus, quality of discussion and behavior to observe the behavioral outcome. Meanwhile, psychological outcome was observed through the questionnaire distributed to students, which meant to observe their enjoyment and motivation using scaled items. Besides the scaled items, the questionnaire also asked open ended questions for the purpose of trying to gauge students' perception towards gamification which might go beyond enjoyment and motivation gained from the gamification process. The scaled items were analyzed using descriptive analysis (using mean) and the open ended questions were analyzed using thematic analysis.

\subsection{Phase 3 - Enhancement of Phase 2: Gamification}

Phase 3 is the enhancement of Phase 2. Instructor repeated the same methodology used in Phase 2. The difference was in the respondent, where Phase 3 involved students taking the same course but in different academic session (Session A172 as compared to A171 in Phase 2). Similar to Phase 2, in Phase 3, students were given a set of questionnaire consisting of the scaled items and open ended questions. The open ended questions, which was analysed using thematic analysis may act as the improvement from Phase 2 to Phase 3.

\subsection{Data Analysis}

The data was analyzed using mixed method of qualitative and quantitative. Three types of data were collected and analyzed:

\section{Data from Participation Rubrics}

This rubric observes several traits that denote participation, such as contributions, attitude towards peers, attitude towards instructor, preparedness, focus, quality of discussion and behaviour. Each trait is scored according to 4 categories:

i) Excellent (16-20 marks) - denotes the participation of every member in a particular group for a specific trait.

ii) Good (11-15 marks) - denotes the participation of maximum $75 \%$ of group members in a particular group for a specific trait. iii) Fair (6-10 marks) - denotes the participation of maximum $50 \%$ of group members in a particular group for a specific trait.

iv) Needs Improvement (1-5 marks) - denotes the participation of maximum $25 \%$ of group members in a particular group for a specific trait.

Besides fulfilling the function in assisting observation on students' class participation, this rubric also serves to understand the behavioural outcome resulting from gamification activity.

\section{Data from questionnaire (Scaled items)}

The purpose of distributing questionnaire is to observe psychological outcome that resulted from the gamification activity. Section A of the questionnaire deals with the demographic information of the students. Meanwhile, Section B observes the motives of participation in the gamification activities. In Section C, students' psychological outcome was assessed using scaled items which utilized the scale of $1-5$ as per below:

i) Scale 1 denotes "Totally Disagree”,

ii) scale 2 denotes "Disagree",

iii) scale 3 signifies "Not Sure",

iv) scale 4 signifies "Agree" and

v) scale 5 implies "Totally Agree”.

The mean for each item was taken to indicate the psychological outcome of students which results from the gamification activity. The questionnaire is adapted from previous research (Cheong, Cheong, \& Flippou, 2013; Witt, Scheiner, \& Robra-Bissantz, 2011)

\section{Data from questionnaire (Open ended items)}

The questionnaire has also included the open-ended question in Section D, which purpose is also to observe students' perception on gamification activity. This data was analysed using thematic analysis.

\section{Results and Findings}

Information in the below sub-sections describes in detail of the findings related to this study, which is discussed according to the phases mentioned in the methodology section. According to Sigala (2015), motivational affordance that is created in the gamification process leads to users' experiential value creation in the forms of psychological or behavioral outcome (Hamari et al., 2014; Sigala, 2015). Psychological outcome usually be interpreted as enjoyment and motivation (Sigala, 2015), while behavioral outcome may be viewed in the form of players' participation (Sigala, 2015). The findings discussed in the following sub-sections reveal the outcomes in term of psychological and behavioral outcomes which are created from motivational affordance in the gamification activities. 


\subsection{Descriptive Information}

The beginning section of the questionnaire distributed asked about the gender of the respondents and the reason for their participation in the gamification activity. The results are stated in Table 1. Majority of the respondents are female in both semesters. With regard to their motives in participating, respondents or students perceive that their motives are for gaining knowledge, having fun and because of competition among peers.

Table 1. Demographic Information

\begin{tabular}{|c|c|c|c|c|}
\hline & \multicolumn{2}{|c|}{ A171 } & \multicolumn{2}{|c|}{ A172 } \\
\hline \multirow[b]{2}{*}{ Gender } & Male & Fen & Male & Female \\
\hline & $\begin{array}{c}6 \\
18.2 \%\end{array}$ & $\begin{array}{c}27 \\
81.8 \% \\
\end{array}$ & $\begin{array}{c}6 \\
33.3 \% \\
\end{array}$ & $\begin{array}{c}12 \\
66.7 \% \\
\end{array}$ \\
\hline $\begin{array}{c}\text { Motives of } \\
\text { participation in } \\
\text { the } \\
\text { gamification } \\
\text { activity }\end{array}$ & \multicolumn{2}{|c|}{$\begin{array}{c}1^{\text {st }} \text { choice: Fun } \\
(42.4 \%) \\
2^{\text {nd }} \text { choice: Knowledge } \\
(27.3 \%) \\
3^{\text {rd }} \text { choice: } \\
\text { Competition }(18.2 \%)\end{array}$} & \multicolumn{2}{|c|}{$\begin{array}{c}1^{\text {st }} \text { choice: Knowledge } \\
(27.8 \%) \\
2^{\text {nd }} \text { choice: Fun } \\
(27.8 \%) \\
3^{\text {rd }} \text { choice: Knowledge } \\
(33.3 \%)\end{array}$} \\
\hline
\end{tabular}

\subsection{Phase 1- Traditional Lecture}

In the "pre-implementation phase", instructor asked students to read the materials uploaded in the online learning for next class' lecture. Upon hearing the instructions, students seemed to understand the task that was put on them. Some of them nodded their heads, but most of them seemed to only listen without really paying attention. Students looked like they are accepting the instructions as part of class routine.

Table 2. Student Group’s Participation Rubric during Traditional Phase

\begin{tabular}{|c|c|c|c|c|c|}
\hline Traits & $\mathrm{N}$ & Poor & Fair & Good & Excellent \\
\hline Contributions & $\begin{array}{c}7 \\
(100.0 \%)\end{array}$ & $\begin{array}{c}0 \\
(0.0 \%)\end{array}$ & $\begin{array}{c}4 \\
(57.1 \%)\end{array}$ & $\begin{array}{c}3 \\
(42.9 \%)\end{array}$ & $\begin{array}{c}0 \\
(0.0 \%)\end{array}$ \\
\hline $\begin{array}{c}\text { Attitude } \\
\text { towards peers }\end{array}$ & $\begin{array}{c}7 \\
(100.0 \%)\end{array}$ & $\begin{array}{c}0 \\
(0.0 \%)\end{array}$ & $\begin{array}{c}4 \\
(57.1 \%)\end{array}$ & $\begin{array}{c}3 \\
(42.9 \%)\end{array}$ & $\begin{array}{c}0 \\
(0.0 \%)\end{array}$ \\
\hline $\begin{array}{c}\text { Attitude } \\
\text { towards } \\
\text { instructor }\end{array}$ & 7 & 0 & 1 & 6 & 0 \\
\hline $\begin{array}{c}\text { Preparedness } \\
(100.0 \%)\end{array}$ & $\begin{array}{c}7 \\
(100.0 \%)\end{array}$ & $\begin{array}{c}0 \\
(14.3 \%)\end{array}$ & $\begin{array}{c}5 \\
(85.7 \%)\end{array}$ & $\begin{array}{c}2 \\
(0.0 \%)\end{array}$ \\
\hline Focus & 7 & 0 & 5 & 2 & 0 \\
$(100.0 \%)$ & $(0.0 \%)$ & $(71.4 \%)$ & $(28.6 \%)$ & $(0.0 \%)$ \\
\hline $\begin{array}{c}\text { Quality of } \\
\text { discussion }\end{array}$ & $\begin{array}{c}7 \\
(100.0 \%)\end{array}$ & $\begin{array}{c}0 \\
(0.0 \%)\end{array}$ & $\begin{array}{c}3 \\
(42.9 \%)\end{array}$ & $\begin{array}{c}4 \\
(57.1 \%)\end{array}$ & $\begin{array}{c}0 \\
(0.0 \%)\end{array}$ \\
\hline Behavior & $\begin{array}{c}7 \\
(100.0 \%)\end{array}$ & $\begin{array}{c}0 \\
(0.0 \%)\end{array}$ & $\begin{array}{c}1 \\
(14.3 \%)\end{array}$ & $\begin{array}{c}6 \\
(85.7 \%)\end{array}$ & $\begin{array}{c}0 \\
(0.0 \%)\end{array}$ \\
\hline
\end{tabular}

In the "during implementation phase", traditional lecture was conducted. Some students listened to the lecture attentively, some of them take notes from the lecture, and some of them just listened and looked like trying to absorb the lecture contents. After the traditional lecture, instructor asked students to group themselves and make discussion in groups. The students reluctantly move themselves to form the groups, and after the groups have been formed, they started to silently discuss the lecture contents, not really eager to do so. After ten minutes, instructor asked questions and requested the students to voluntarily suggest some answers. However, no one in the class had put up his/her hand to answer the questions voluntarily. In the end, instructor needed to call students' names in order to make them answer the questions posed, which they did. Instructor recorded the observation on students groups' participation using participation rubric. The results are outlined in Table 2.

Students formed themselves into seven groups. From Table 2 above, it can be observed that the group of students participated in the range of "fair" to "good" in every trait when the class was conducted using traditional lecture. For the traits "Preparedness" and "Focus", most of the groups (5 out of 7 groups) show "fair" level of preparation and focus, where only $50 \%$ of group members were actually following the lecture, having necessary materials and stay focused on the lecture. However, in term of "Attitude towards Instructor" and "Behavior", the results show that most of the group members (6 out of 7 groups) have "good" attitude towards instructor and without disruptive behavior.

\subsection{Phase 1 - Reflection}

In phase 1, when traditional lecture was solely used, students seemed to be passive, indifferent and reluctant to participate. Even when they sat in groups and required to perform group discussion, the discussion made was merely to follow instruction, without the eagerness in accumulating and transmitting knowledge among the group members. Students did not volunteer to answer when questions were posed, rather sat quietly until their named were called.

This situation marks that when traditional lecture is not supplanted by other active teaching methods, the level of participation by students would be low. They will tend to be passive, uninterested and just following instructions as part of class routine.

\subsection{Phase 2 - Gamification}

In phase 2, during the "pre-implementation session", instructor asked students to read the materials uploaded in the online learning for next class' lecture, and announced that a game would be conducted at the end of the session and the winning teams will be rewarded. Upon hearing the announcement, the atmosphere suddenly changed where students seemed to be totally excited. Most of them jovially talked to friends about the possibility of becoming the winning team.

In the "during implementation phase", traditional lecture was conducted. Students listened to the lecture attentively and took notes on the lecture. When asked to form groups, they moved swiftly and excitedly, and the group discussion was alive. After ten minutes, instructor briefed students on the game instruction and the game began. Students were 
seen to pay their fullest attention to the gamification activity, participated actively as group members in making sure that their respective groups win the game.

Students formed themselves into seven groups. Results in Table 3 indicate that when gamification was conducted, students' atmosphere of class participation has changed, where they participated in the range of "fair" to "excellent". The range "excellent" means that every member in the group has participated actively, and this can be seen across all traits. Only one group show "fair" level of participation in certain traits which are the "Contributions", "Focus" and “Quality of Discussion”, which indicate only 50\% of group members' participation. These results indicate that the gamification activity has enhanced the level of students' participation, which signifies their behavioral outcome resulted from the gamification activity.

Table 3. Students' Behavioral Outcome from Gamification Process (Phase 2)

\begin{tabular}{|c|c|c|c|c|c|}
\hline Traits & $\mathrm{N}$ & Poor & Fair & Good & Excellent \\
\hline Contributions & $\begin{array}{c}7 \\
(100.0 \%)\end{array}$ & $\begin{array}{c}0 \\
(0.0 \%)\end{array}$ & $\begin{array}{c}1 \\
(14.2 \%)\end{array}$ & $\begin{array}{c}3 \\
(42.9 \%)\end{array}$ & $\begin{array}{c}3 \\
(42.9 \%)\end{array}$ \\
\hline $\begin{array}{c}\text { Attitude } \\
\text { towards peers }\end{array}$ & $\begin{array}{c}7 \\
(100.0 \%)\end{array}$ & $\begin{array}{c}0 \\
(0.0 \%)\end{array}$ & $\begin{array}{c}0 \\
(0.0 \%)\end{array}$ & $\begin{array}{c}4 \\
(57.1 \%)\end{array}$ & $\begin{array}{c}3 \\
(42.9 \%)\end{array}$ \\
\hline $\begin{array}{c}\text { Attitude } \\
\text { towards } \\
\text { instructor }\end{array}$ & $\begin{array}{c}7 \\
(100.0 \%)\end{array}$ & $\begin{array}{c}0 \\
(0.0 \%)\end{array}$ & $\begin{array}{c}0 \\
(0.0 \%)\end{array}$ & $\begin{array}{c}2 \\
(28.6 \%)\end{array}$ & $\begin{array}{c}5 \\
(71.4 \%)\end{array}$ \\
\hline Preparedness & 7 & 0 & 0 & 3 & 4 \\
$(100.0 \%)$ & $(0.0 \%)$ & $(0.0 \%)$ & $(42.9 \%)$ & $(57.1 \%)$ \\
\hline Focus & 7 & 0 & 1 & 3 & 3 \\
$(100.0 \%)$ & $(0.0 \%)$ & $(14.2 \%)$ & $(42.9 \%)$ & $(42.9 \%)$ \\
\hline $\begin{array}{c}\text { Quality of } \\
\text { discussion }\end{array}$ & $\begin{array}{c}7 \\
(100.0 \%)\end{array}$ & $\begin{array}{c}0 \\
(0.0 \%)\end{array}$ & $\begin{array}{c}1 \\
(14.2 \%)\end{array}$ & $\begin{array}{c}3 \\
(42.9 \%)\end{array}$ & $\begin{array}{c}3 \\
(42.9 \%)\end{array}$ \\
\hline Behavior & $\begin{array}{c}7 \\
(100.0 \%)\end{array}$ & $\begin{array}{c}0 \\
(0.0 \%)\end{array}$ & $\begin{array}{c}0 \\
(0.0 \%)\end{array}$ & $\begin{array}{c}3 \\
(42.9 \%)\end{array}$ & $\begin{array}{c}4 \\
(57.1 \%)\end{array}$ \\
\hline
\end{tabular}

Table 4. Individual Students' Psychological Outcome from Gamification Process

\begin{tabular}{|l|c|c|}
\hline \multicolumn{1}{|c|}{ Engagement } & Mean & SD \\
\hline I wanted to complete the Kahoot! game. & 4.67 & 0.60 \\
\hline I found the Kahoot! game satisfying. & 4.73 & 0.57 \\
\hline I felt absorbed in the Kahoot! game. & 4.55 & 0.67 \\
\hline $\begin{array}{l}\text { Time passed quickly for me during the } \\
\text { Kahoot! game. }\end{array}$ & 4.33 & 0.89 \\
\hline I felt excited during the Kahoot! game. & 4.82 & 0.39 \\
\hline \begin{tabular}{l} 
Enjoyment \\
\hline $\begin{array}{l}\text { I felt happy when playing the Kahoot! } \\
\text { game. }\end{array}$
\end{tabular} & 4.70 & 0.47 \\
\hline $\begin{array}{l}\text { I don't feel worried when playing the } \\
\text { Kahoot! Game. }\end{array}$ & 3.44 & 1.25 \\
\hline Task Involvement & 4.70 & 0.47 \\
\hline It was enjoyable to play the Kahoot! Game. & 4.64 & 0.49 \\
\hline It was interesting to play the Kahoot! Game. & 4.45 & 0.67 \\
\hline $\begin{array}{l}\text { It was stimulating to play the Kahoot! } \\
\text { Game. }\end{array}$ & 4.79 & 0.42 \\
\hline It was exciting to play the Kahoot! Game. & & \\
\hline
\end{tabular}

At the end of the class session, when the game has ended, instructor distribute questionnaire to assess students' psychological behavior. Results of the Part A of the questionnaire are outlined in Table 4.

There were 35 students who took part in filling the questionnaire. Results in Table 4 suggest that students' agree in every item that gamification process has enhanced their engagement and involvement in classroom activities, and they enjoyed themselves during the process, and the gamification activity has able to stimulate students' involvement.

In Part B of the questionnaire, students were asked of the overall comments on gamification in classroom. The data was analyzed using thematic analysis. The results suggest that students perceived gamification in classroom in a number of themes as discussed below. Some quotes from students are also provided:

\begin{tabular}{|c|c|c|}
\hline No & Theme & Quotes \\
\hline 1. & $\begin{array}{l}\text { Enjoyable } \\
\text { and fun }\end{array}$ & $\begin{array}{l}\text { "It is fun. It should be included as one of } \\
\text { classroom activities to attract students' } \\
\text { attention to focus in the class". } \\
\text { "It is fun when we have game in classroom. I } \\
\text { feel more attracted to the topic". }\end{array}$ \\
\hline 2. & $\begin{array}{c}\text { Attractive } \\
\text { and exciting }\end{array}$ & $\begin{array}{l}\text { "When the class enjoy, will attract students } \\
\text { coming to class". } \\
\text { "It is very exciting and help students to } \\
\text { understand the topic better. }\end{array}$ \\
\hline 3. & $\begin{array}{l}\text { Enhancing } \\
\text { knowledge }\end{array}$ & $\begin{array}{l}\text { "Give advantage for us to get extra } \\
\text { knowledge when discussing in our group to } \\
\text { choose the best answer". } \\
\text { "It's very fun. I learn more knowledge and } \\
\text { information that I don't know when playing } \\
\text { the game". } \\
\text { "Getting knowledge in interesting way". } \\
\text { "Gamification develop critical thinking } \\
\text { skills". }\end{array}$ \\
\hline 4. & $\begin{array}{c}\text { Increase } \\
\text { participation }\end{array}$ & $\begin{array}{l}\text { "Kahoot! allow us to involve with other } \\
\text { members, stimulate the bonding and more } \\
\text { participation". } \\
\text { "Through games, we can cooperate with } \\
\text { friends more than just usual class activity". }\end{array}$ \\
\hline 5. & Motivating & $\begin{array}{l}\text { "Kahoot! game make us want answer fast and } \\
\text { get the best score". } \\
\text { "It motivate me to come to class. It attract } \\
\text { more attention compare to normal } \\
\text { presentation as usual". } \\
\text { "Reward can increase motivation for } \\
\text { students'. }\end{array}$ \\
\hline 6. & $\begin{array}{l}\text { Should be } \\
\text { conducted } \\
\text { more }\end{array}$ & $\begin{array}{l}\text { "Need to be done every time after each } \\
\text { chapter finished". } \\
\text { "For me, it is fun and need to frequently } \\
\text { done". }\end{array}$ \\
\hline 7. & Teamwork & $\begin{array}{l}\text { "Gamification also can develop teamwork } \\
\text { skills". } \\
\text { "It encourage team building spirit and } \\
\text { cooperation". }\end{array}$ \\
\hline
\end{tabular}

\subsection{Phase 2 - Reflection}

In phase 2, the class atmosphere had begun to change when instructor announced that a game activity will be conducted. Students listened attentively to the traditional lecture, swiftly moved to form groups when instructed to do so. The group discussion was alive, students were found 
to put their fullest effort in making sure that everybody in the group grasp the course content fully.

The gamification activity was participated by the students with full enjoyment. They engaged with the activity, provided full participation and gave the best to their team. They enjoyed the game and suggested that gamification activity to be conducted more.

\subsection{Phase 3 - Gamification}

In phase 3, instructor repeats the cycle using the actions in phase 2, however in different class setting. The reason of repeating the same cycle is to observe if different perception on gamification may be observed among students in different session.

In the pre-implementation stage, the silent atmosphere in the classroom suddenly changed when the instructor announced that there will be a game conducted after the discussion session. Results of "during-implementation" stage also showed similarity to those in phase 2 (see Table 5). Students "excellently" participated in the class activity which means that every member in every group has participated actively, and this can be seen across all traits. These results indicate that the gamification activity has enhanced the level of students' participation, which signifies their behavioral outcome resulted from the gamification activity.

Table 5. Students' Behavioral Outcome from Gamification Process (Phase 3)

\begin{tabular}{|c|c|c|c|c|c|}
\hline Traits & $\mathrm{N}$ & Poor & Fair & Good & Excellent \\
\hline Contributions & $\begin{array}{c}5 \\
(100.0 \%)\end{array}$ & $\begin{array}{c}0 \\
(0.0 \%)\end{array}$ & $\begin{array}{c}0 \\
(0.0 \%)\end{array}$ & $\begin{array}{c}2 \\
(40.0 \%)\end{array}$ & $\begin{array}{c}3 \\
(60.0 \%)\end{array}$ \\
\hline Attitude towards peers & $\begin{array}{c}5 \\
(100.0 \%)\end{array}$ & $\begin{array}{c}0 \\
(0.0 \%)\end{array}$ & $\begin{array}{c}0 \\
(0.0 \%)\end{array}$ & $\begin{array}{c}2 \\
(40.0 \%)\end{array}$ & $\begin{array}{c}3 \\
(60.0 \%)\end{array}$ \\
\hline Attitude towards instructor & $\begin{array}{c}5 \\
(100.0 \%)\end{array}$ & $\begin{array}{c}0 \\
(0.0 \%)\end{array}$ & $\begin{array}{c}0 \\
(0.0 \%)\end{array}$ & $\begin{array}{c}0 \\
(0.0 \%)\end{array}$ & $\begin{array}{c}5 \\
(100 \%)\end{array}$ \\
\hline Preparedness & $\begin{array}{c}5 \\
(100.0 \%) \\
\end{array}$ & $\begin{array}{c}0 \\
(0.0 \%) \\
\end{array}$ & $\begin{array}{c}0 \\
(0.0 \%) \\
\end{array}$ & $\begin{array}{c}3 \\
(60.0 \%) \\
\end{array}$ & $\begin{array}{c}2 \\
(40.0 \%) \\
\end{array}$ \\
\hline Focus & $\begin{array}{c}5 \\
(100.0 \%)\end{array}$ & $\begin{array}{c}0 \\
(0.0 \%)\end{array}$ & $\begin{array}{c}0 \\
(0.0 \%)\end{array}$ & $\begin{array}{c}1 \\
(20.0 \%)\end{array}$ & $\begin{array}{c}4 \\
(80.0 \%)\end{array}$ \\
\hline Quality of discussion & $\begin{array}{c}5 \\
(100.0 \%)\end{array}$ & $\begin{array}{c}0 \\
(0.0 \%)\end{array}$ & $\begin{array}{c}0 \\
(0.0 \%)\end{array}$ & $\begin{array}{c}2 \\
(40.0 \%)\end{array}$ & $\begin{array}{c}3 \\
(60.0 \%)\end{array}$ \\
\hline Behavior & $\begin{array}{c}5 \\
(100.0 \%)\end{array}$ & $\begin{array}{c}0 \\
(0.0 \%)\end{array}$ & $\begin{array}{c}0 \\
(0.0 \%)\end{array}$ & $\begin{array}{c}1 \\
(20.0 \%)\end{array}$ & $\begin{array}{c}4 \\
(80.0 \%)\end{array}$ \\
\hline
\end{tabular}

Table 6. Individual Students' Psychological Outcome from Gamification Process

\begin{tabular}{|l|c|c|}
\hline \multicolumn{1}{|c|}{ Engagement } & Mean & SD \\
\hline I wanted to complete the Kahoot! game. & 4.67 & 0.59 \\
\hline I found the Kahoot! game satisfying. & 4.67 & 0.49 \\
\hline I felt absorbed in the Kahoot! game. & 4.50 & 0.62 \\
\hline Time passed quickly for me during the Kahoot! game. & 4.50 & 0.71 \\
\hline I felt excited during the Kahoot! game. & 4.50 & 0.51 \\
\hline Enjoyment & & \\
\hline I felt happy when playing the Kahoot! game. & 4.67 & 0.49 \\
\hline I do not feel miserable during the Kahoot! Game. & 3.89 & 1.02 \\
\hline Task Involvement & & \\
\hline It was enjoyable to play the Kahoot! Game. & 4.67 & 0.49 \\
\hline It was interesting to play the Kahoot! Game. & 4.78 & 0.43 \\
\hline It was stimulating to play the Kahoot! Game. & 4.50 & 0.62 \\
\hline It was exciting to play the Kahoot! Game. & 4.67 & 0.59 \\
\hline
\end{tabular}


There were 18 students who took part in filling the questionnaire. Results in Table 6 suggest that students' agree in every item that gamification process has enhanced their engagement and involvement in classroom activities, and they enjoyed themselves during the process, and the gamification activity has able to stimulate students' involvement.

In Part B of the questionnaire, students were asked of the overall comments on gamification in classroom. The data was analyzed using thematic analysis. The results suggest that students perceived gamification in classroom in a number of themes. The themes perceived by students in phase 3 is more likely similar to those of in phase 2 (enjoyable and fun, attractive and exciting, enhancing knowledge, increase participation), but for a few exceptions. In phase 2, students perceived gamification as enhancing motivation, developing teamwork skills and need to be conducted more, however these themes were not found during phase 3. Furthermore, in phase 3, students perceived that the knowledge that has been obtained from gamification activity leads to competition between groups. Students also perceived that gamification enhance bonding not only between students but also between students and lecturer or instructor. Some quotes from students in phase 3 are provided below:

\begin{tabular}{|c|c|c|}
\hline No & Theme & Quotes \\
\hline 1. & $\begin{array}{l}\text { Enjoyable and } \\
\text { fun }\end{array}$ & $\begin{array}{l}\text { "It is fun and exciting". } \\
\text { "It was enjoyable to play the Kahoot! } \\
\text { game". }\end{array}$ \\
\hline 2. & $\begin{array}{l}\text { Attractive and } \\
\text { exciting }\end{array}$ & $\begin{array}{l}\text { "Best platform to attract students to pay } \\
\text { attention in class during the learning } \\
\text { process". } \\
\text { "It was exciting when playing Kahoot! } \\
\text { game in class. }\end{array}$ \\
\hline 3. & $\begin{array}{l}\text { Enhancing } \\
\text { knowledge }\end{array}$ & $\begin{array}{l}\text { "Easy to gain knowledge". } \\
\text { "Simple way for students to understand } \\
\text { the topic". } \\
\text { "We gain more knowledge and able to } \\
\text { remember some of keypoints related to } \\
\text { the topic". }\end{array}$ \\
\hline 4. & $\begin{array}{r}\text { Increas } \\
\text { participat }\end{array}$ & $\begin{array}{l}\text { "Can attract students to participate in } \\
\text { class". }\end{array}$ \\
\hline 5. & Competition & $\begin{array}{l}\text { "We can use our knowledge to compete } \\
\text { with other groups". }\end{array}$ \\
\hline 6. & Bonding & $\begin{array}{l}\text { "Game activity is the way to get close } \\
\text { between students and the lecturer". }\end{array}$ \\
\hline
\end{tabular}

\subsection{Phase 3 - Reflection}

In phase 3 , researcher repeat the cycle which was conducted in phase 2, however, the objective is more focused on the themes perceived by students with regard to gamification. Similar to phase 2, the motivational affordance created from gamification activity has enhanced the psychological outcome, which can be seen through students perception on their level of engagement, enjoyment and task involvement. Furthermore, students' behavioral outcome may also be observed through their level of participation. These results suggest that students feel that they possess the ability to interact with the gamification activity, they feel that they have the capacity to engage in the activity, therefore, they have participated well in the activity.

With regard to the themes, similar results to phase 2 has been observed. Students perceived that gamification activity is enjoyable and fun, attractive and exciting, enhancing knowledge, increase participation. However, some unique themes was also found in phase 3. Students felt that gamification also enhance bonding not only between students but also between students and lecturer or instructor, besides promoting competition between groups.

\section{Conclusions}

The purpose of this study is to observe if gamification enhance students' class participation. Using the setting of BKAM3073 course, several phases of actions were conducted to witness whether motivational affordance which resulted from the gamification activities leads to psychological outcome in the form of engagement, enjoyment and involvement, and finally points to behavioral outcome in the form of participation.

In phases 1 , where traditional lecture was conducted, the class atmosphere was passive and mundane. However, in phase 2 and phase 3 , when gamification was conducted, the atmosphere of the class becomes active and exciting. At the end of the class in both phases 2 and 3, students admitted that gamification has triggered them to engage and involve with the game activity and they really enjoyed the game. Similar results found in phases 2 and 3 may be due to the similarity in the students' demographic background such as their age and their year of study, therefore, their similar preference to active learning style was observed.

Self-determination Theory (SDT) posits that motivation will drive humans to conduct their choices. The findings of this study shows that gamification has triggered motivational affordance in the students to which leads to behavioral outcome which shown through their willingness to engage and involve and enjoying themselves throughout the game activity. Furthermore, findings also suggest that when students have positive behavior towards the gamification process, they expose their psychological outcome, which may be seen in their participation in the game activity. Students also perceived that gamification activity increases participation, improving motivation, creating competition, developing teamwork and bonding between students and lecturers and should be conducted more.

The above discussion supports the initial prediction on the role played by gamification in enhancing students' class participation. The findings from this study provides support to the benefit of using technology in classroom, which not only benefit the students, who are the main 
object in deliverance of knowledge, but also to instructors, who will have alternatives in attracting students' attention and participation in classroom, compared to solely dependent to the usage of traditional lecture.

This study is not without limitation, as it focus on the outcome of the motivational affordance which results from gamification. Further studies may consider to what extent gamification leads to students' motivation in performing what they belief they could achieve.

\section{Acknowledgements}

This research work is supported by the Universiti Utara Malaysia (SOTL Grant; SO Code 13832).

\section{REFERENCES}

[1] Aliaga, M., Cobb, G., Cuff, C., Garfield, J., Gould, R., Lock, R., Moore, T., Rossman, A., Stephenson, B., Utts, J., Velleman, P., \& Witmer, J. (2010). Guidelines for Assessment and Instruction in Statistics Education (GAISE). Alexandria, Virginia: American Statistical Association.

[2] Barata, G., Gama, S., Jorge, J., \& Goncalves, D. (2013). IMroving Participation and Learning with Gamification. Paper presented at the Gamification 2013, Stratford, Ontario, Canada.

[3] Borges, S. d. S., Durelli, V. H. S., Reis, H. M., \& Isotani, S. (2014). A Systematic Mapping on Gamification Applied to Education Paper presented at the SAC, Gyeongju, South Korea.

[4] Cheong, C., Cheong, F., \& Flippou, J. (2013). Quick Quiz: A Gamified Approach for Enhancing Learning. Paper presented at the Pacific Asia Conference on Information Systems, Jeju Island, Korea.

[5] Connoli, T. M., Boyle, E. A., MacArthur, E., Hainey, T., \& Boyle, J. M. (2012). A Systematic Literature Review of Empirical Evidence on Computer Games and Serious Games. Computer and Education, 59(2), 661-686. doi: 10.1016/j.compedu.2012.03.004

[6] de-Marcos, L., Dominguez, A., Saenz-de-Navarette, J., \& Pages, C. (2014). An Empirical Study Comparing Gamification and Social Networking on e-Learning. Computer and Education, 75, 82-91. doi: 10.1016/j.compedu.2014.01.012

[7] Dellos, R. (2015). Kahoot! A digital game resource for learning. International Journal of Instructional Technology and Distance Learning, 12(4).

[8] Deterding, S. (2011). Situated Motivational Affordances of Game Elements: A Conceptual Model. Paper presented at the ACM CHI Conference on Human Factors in Computing Systems, Vancouver, British Columbia.

[9] Dolnicar, S. (2005). Should We Still Lecture or Just Post Examination Questions on the Web? The Nature of the Shift Towards Pragmatism in Undergraduate Lecture Attendance.
Quality in Higher Education, 11(2), 103-115.

[10] Elis, D. (2015). Using Padlet to Increase Student Engagement in Lectures. Paper presented at the European Conference on e Learning, Hatfield, United Kingdom.

[11] Fuchs, B. (2014). The Writing is on the Wall: Using Padlet for Whole-Class Engagement LOEX Quarterly, 4.

[12] Gee, J. P. (2003). What Video Games Have to Teach Us About Learning Literacy. Computer Entertainment, 1(1), 20-20.

[13] Hamari, J., Koivisto, J., \& Sarsa, H. (2014). Does Gamification Work? - A Literature Review of Empirical Studies on Gamification. Paper presented at the 47th Hawaii International Conference on System Science, Hawaii.

[14] Isaacs, G. (1989). Lecture Note-taking, Learning and Recall. Medical Teacher, 11(3-4), 295-302.

[15] Kapp, K. M. (2012). The Gamification of Learning and Instruction: Game-based Methods and Strategies for Training and Education (1st Edition). San Francisco, CA: John Wiley \& Sons.

[16] Kiryakova, D., Angelova, N., \& Yordanova, L. (2014). Gamification in Education. Paper presented at the 9th International Balkan Education and Science Conference, Edirne, Turkey.

[17] Lee, J., \& Hammer, J. (2011). Gamification in Education: What, How, Why Bother? Academic Exchange Quarterly, 15(2), 1-5.

[18] McGarr, O. (2009). A Review of Podcasting in Higher Education: Its Influence on the Traditional Lecture. Australasian Journal of Educational Technology, 25(3), 309-321.

[19] McNiff, J. (2010). Action Research for Professional Development: Concise Advice for New Action Research. Dorset: September Books.

[20] Nehring, N., Baghaei, N., \& Dacey, S. (2018). Improving Student' Performance through Gamification: A User Study. Paper presented at the 10th International Conference on Computer Supported Education, Funchal, Portugal.

[21] O'Donovan, S., Gain, J., \& Marais, P. (2013). A Case Study in the Gamification of a University-Level Games Development Course. Paper presented at the The South African Institute for Computer Scientists and Information Technologists Conference, East London, SOuth AFrica.

[22] Seaborn, K., \& Fels, D. I. (2015). Gamification in Theory and Action: A Survey. International journal of Human-Computer Studies, 74, 14-31. doi: 10.1016/j.ijhcs. 2014.09.006

[23] Sigala, M. (2015). The Application and Impact of Gamification Funware on Trip Planning and Experiences: the Case of TripAdvisor's Funware. Electron Markets, 25(3), 189-209.

[24] Surendeleg, G., Murwa, V., Yun, H.-K., \& Kim, Y. S. (2014). The Role of Gamification in Education - a Literature Review. Contemporary Engineering Sciences, 7(29), 1606-1616. doi: 10.12988/ces.2014.411217 
[25] Takahashi, D. (2008). Funware's Threat to the Traditional Video Game Industry.https://venturebeat.com/2008/05/09/ funwares-threat-to-the-traditional-video-game-industry/

[26] Thibes, S., Lins, S., \& Basten, D. (2014). Gamifying Information Systems - Synthesis of Gamification Mechanics and Dynamics. Paper presented at the European Conference on Information Systems (ECIS), Tel Aviv, Israel.

[27] Vandrick, S. (2000). Language, Culture, Class, Gender, and Class Participation. Paper presented at the Annual Meeting of Teachers of English to Speakers of Other Languages, Vancouver, Canada.

[28] Witt, M., Scheiner, C., \& Robra-Bissantz, S. (2011). Gamification of Online Idea Competitions: Insights from an Explorative Case. Paper presented at the Informatik, Berlin. 